\title{
Buddhist law in early Tibet: the emergence of an ideology
}

Fernanda Pirie, Professor of the Anthropology of Law, University of Oxford

\begin{abstract}
Tibet is distinct within the Buddhist regions of Asia for its claims to have developed religious laws. The rulers of its early empire civilized their people by creating laws on the basis of Buddhist principles-or so it is claimed by the writers of Tibetan historical narratives. In fact, the earliest Tibetan laws were not linked in any significant way with Buddhist principles, even after the religion had been firmly established in the region. This paper asks why and how the idea of Buddhist law first emerged, examining its development through a number of texts from the empire (sixth to ninth centuries) and the immediate post-imperial period (tenth to twelfth centuries). It turns out that more ideological accounts of Buddhist law were only developed as the structures of the empire were collapsing. Nevertheless, they do seem to have resonated with at least one, tenth-century ruler. These narratives set the scene for a long series of historical accounts, in which the idea that Tibetan law was based on Buddhist principles took hold, and which was maintained well into the twentieth century.
\end{abstract}

Key words: Buddhist law, Tibet, Buddhism, legal ideology, medieval history

How did the concept of Buddhist law emerge in Tibet? In a long series of historical narratives Tibetan writers described how the rulers of their early empire had received religious texts, introduced writing, and created laws; after this, their realm expanded and prospered. These rulers, it was said, created law on the basis of the ten (Buddhist) virtues. Forms of this account were elaborated and retold in different forms from around the eleventh to the twentieth centuries. Within the Buddhist regions of Asia, Tibet is unusual in making such bold claims to have developed Buddhist law, and writers on other parts of the region have been hesitant to label any texts or practices as 'Buddhist law'. The Vinaya-early rules for monastic conduct-and dhammasattha texts-Burmese rules for the laity-might plausibly claim this label, but they do not seem to have been presented as Buddhist law by those who made and used them. ${ }^{1}$ The Tibetans who asserted a firm religious identity for their

\footnotetext{
${ }^{1}$ Rebecca Redwood French and Mark A. Nathan's Buddhism and Law: An Introduction (Cambridge: University Press, 2014) contains a fine collection of papers on the relationship between Buddhism and law. The Vinaya and dhammasatta texts are discussed by Christian Lammerts, "Genres and Jurisdictions: Laws Concerning Monastic Inheritance in Seventeenth-Century Burma", in Buddhism and Law, ed. French and Nathan, 183-97. The Mongols also created what they described as
} 
law are, therefore, something of an exception. In this paper I ask how the idea of Buddhist law first emerged. ${ }^{2}$

Evidence from the empire of the seventh to ninth centuries indicates that the legal system developed during this period was not, in fact, founded on Buddhist ideas. It was only as the political structures were collapsing, some two centuries after Buddhism had been affirmed as the state religion, that Tibetan writers re-presented their legal project as a religious one. In the tenth and eleventh centuries, texts began to claim that the early Tibetan kings had based their laws on the Buddhist texts they had received from India, thereby civilizing their people and establishing a Buddhist kingdom. Why and how did the writers develop these ideas? And how did the new ideas about law relate to changing attitudes towards administrative order and government? As I describe here, although the concept of Buddhist law was primarily ideological and there were inconsistencies between Buddhist moral ideals and the reality of legal practices, the idea took hold and had lasting influence. ${ }^{3}$

\section{The Tibetan empire: government, law, and Buddhism}

Already in the seventh century, the rulers who united the powerful clans of central Tibet had established a court and a bureaucracy with distinct offices and ranks of ministers. This followed the development of a written form of the Tibetan language, used by the military and by merchants engaged in international trade along the silk roads. ${ }^{4}$ Some of the early emperors were sympathetic to Buddhism and made marital alliances with China, where the religion was already established. New queens arrived with a retinue of Buddhist adherents and sacred statutes, and founded new temples on the plateau. There was, however, opposition to the religion, notably in the early eighth century, when a devastating plague led some to suspect the malign influence of the new practitioners and

'Buddhist laws', at times influenced by Tibetan scholarship, see Vesna Wallace, "Buddhist Laws in Mongolia", in Buddhism and Law, ed. French and Nathan, 319-33. In this paper, I use the term 'Buddhist law' to refer to any idea, historical or contemporary, that law was based on Buddhist principles. It is not just a reference to the Vinaya, or other monastic codes.

${ }^{2}$ Rebecca French, The Golden Yoke: The Legal Cosmology of Buddhist Tibet (Ithaca: Cornell University Press, 1995) describes the Tibetan texts and practices that claimed to represent Buddhist principles and cosmology in later periods.

${ }^{3}$ This paper is based on a review of texts from the imperial and post-imperial periods. The aim is not so much to offer new interpretations of individual texts as to ask a more sociological question about the development of Tibetan ideas about law, khrims. I transcribe common Tibetan terms and names according to common modern pronounciation, and otherwise use the Wylie system of transliteration.

${ }^{4}$ Tsuguhito Takeuchi, "The Tibetan Military System and Its Activities from Khotan to Lop-Nor", in The Silk Road: Trade, Travel, War and Faith, ed. S. Whitfield (London: The British Library, 2004), 50-56. 
institutions. It was not until the rein of Tri Song Detsen (Khri Srong IDe btsan), in the late eighth century, that Buddhism was officially endorsed as the state religion, and even this did not occur without opposition.

One question that has been addressed by many writers is why the Tibetan emperors adopted Buddhism. What was the attraction of a religion that emphasized piety and compassion to the ruler of an empire based largely on military conquest? And what changed in Tibet, in terms of administrative practices, political structures, and the ideas that underpinned them? Kapstein and van Schaik suggest a major attraction of Buddhism was that it was an international religion, whose cultural symbols were recognized widely-in China, India, central Asia, and beyond. ${ }^{5}$ Tibetan elites would have been keenly aware of the long histories of the established civilizations that surrounded them. The patronizing attitudes of the kings of Nepal and China-recounted in later histories - to an early king's requests for marriage alliances, may well reflect historical reality. ${ }^{6}$ It seems natural that Tri Song Detsen should have wanted to emulate these regimes by establishing himself as a ruler who participated in their great religious traditions.

Kapstein suggests that Buddhism also provided the Tibetans with a system of organized knowledge. Its trained scholars and scribes, methods of translation, libraries, catalogues, and the systematization of reason and debate, provided a basis for bureaucratic government. ${ }^{7}$ The Buddhist framework of universal laws offered a model for the expanding administration, while the cosmology of karma might, then, have reinforced law and order. ${ }^{8}$ However, as I describe here, it does not seem that Tibetan laws were, in this early period, modelled on religious precedents. The emperors' adoption of Buddhism involved the patronage of monks, temples, and rituals, without the development of a religious legal ideology. Maybe this should not be a surprise. By the late eighth century, the imperial bureaucracy had almost certainly established successful administrative and judicial systems. Moreover, Buddhist texts that dealt with the nature of kingship were notably unfitted for an expanding and war-like empire. Symbols of Buddhism could be adopted, monasteries could be founded, and texts could be translated, without reworking political and legal systems.

\footnotetext{
${ }^{5}$ Matthew Kapstein, The Tibetans (Oxford: Blackwell, 2006), ch.3; Sam van Schaik, Tibet: A History (London: Yale University Press, 2011), 30-32.

${ }^{6}$ This story, concerning Songtsen Gampo, is found in many accounts, including the twelfth-century $b K a^{\prime}$ chems ka khol ma, ed. sMon lam rGya mtsho (Lanzhou: Kan su'u Mi rigs dpe skrun khang, 1989), and in the thirteenth-century Me tog snying po sbrang rtsi'i bud by Nyang ral nyi ma'i 'od zer, (Lhasa: Bod ljongs mi dmangs dpe skrun khang, 1988)

${ }^{7}$ Matthew Kapstein, The Tibetan Assimilation of Buddhism (Oxford: University Press, 2000), 56; The Tibetans, 71.

${ }^{8}$ Kapstein, Tibetan Assimilation, 54, 58.
} 
An examination of both legal and other texts sheds some light on these issues. Ideas of divine kingship and imperial glory characterize a number of Tibetan accounts written in the late eighth and early ninth centuries. These present the imperial dominion as one of good order and excellent customs, and indicate little influence from the model of kingship presented in Buddhist texts. Nor are laws and law-making at all central to these accounts. Tibetans' ideas about the imperial order, their new religion, and their laws seem to have remained conceptually distinct, at least until some time later. In the following sections of this paper I describe what our sources reveal about the ideas and accounts of this period.

\section{Imperial laws}

Pillar inscriptions, along with documents recovered from the library cave at Dunhuang, depict the emergence and expansion of an empire based largely on military conquest. ${ }^{9}$ It developed an extensive bureaucracy, with a complicated system of ranks and offices, which may have emulated Chinese models. The earliest reference to law-making is found in the Old Tibetan Annals, a year-byyear summary of imperial activities from 641 until 734, which appears to be based on contemporaneous records. ${ }^{10}$ The entry for the year 655-56 records that the emperor's chief minister made a $b k a^{\prime}$ grims kyi yi ge, a legal edict. Grims is an early spelling of what became the more familiar khrims, generally translated as 'law'. This followed the emperor's creation of a rtsis mgo, an administrative manual or plan, the previous year. This is the only entry in the Annals that refers directly to law.

If the making of khrims was not thought to merit further record in the Annals, other contemporary documents indicate considerable legal activity. Most of the surviving texts have been recovered at Dunhuang, an important entrepôt connecting several trade routes, to the north east of the central plateau. It was controlled by Tibet between around 787 and 845 , the period from which most of the legal texts probably date. Among them are law codes, which specify the compensation or punishment due in cases of injury or theft. ${ }^{11}$ Two of these (PT 1071/1072 and PT 1073) relate to

\footnotetext{
${ }^{9}$ The 'library cave' at Dunhuang, which was sealed in the early eleventh century and not reopened until 1900, is the main source of written texts from the imperial period: Rong Xinjiang, "The Nature of the Dunhuang Library Cave and the Reasons for its Sealing", Cahiers d'Extreme-Asie 11 (19992000), 247-75; Yoshiro Imaeda, "The Provenance and Character of the Dunhuang Documents", Memoirs of the Toyo Bunko 66 (2008): 81-102.

${ }^{10}$ The text of the Annals that survived at Dunhuang seems to be a copy made for local purposes, albeit clearly from contemporary sources, possibly wooden slips on which a brief record of the events of each year was recorded: Brandon Dotson, The Old Tibetan Annals (Wien: Verlag der Österreichschen Akademie der Wissenschaften, 2009), 10-11.

${ }^{11}$ These are PT 1071/1072, PT 1073, and ITJ 753/PT 1075, discussed in High Richardson, High Peaks and Pure Earth: Collected Writings on Tibetan History and Culture, ed. M. Aris (London: Serindia
} 
injuries or death on the hunting field. They are long documents with multiple clauses, providing for compensation of various kinds, punishment, and exile. The rules are not entirely practical, being too complicated and specific for direct application in all cases, suggesting that they had exemplary, as much as pragmatic, purposes. In particular, they distinguish nine different social classes, including seven ministerial ranks. ${ }^{12}$ As I have suggested elsewhere, ${ }^{13}$ this indicates a clan-based society, characterized by relations of revenge, over which the early emperors were asserting more centralized control, not least by drawing their leaders into a system of aristocratic ranking.

It is evident that some laws, khrims, were referred to during the resolution of legal disputes. Records of several individual cases have been reviewed by Dotson. ${ }^{14}$ As he describes, they often refer to gnya' khrims, rules governing the role of guarantors. There are also references to khrims in general, in records of cases concerning assault and injury, theft of property, the use and ownership of land, and the ownership and exchange of female bondservants, and in a code for the military. The hunting code, itself, refers to other laws, the thong myi khrims, which seem to be laws of homicide, and to the thong myi'i skur pa zan dang khrims, relating to false accusations of homicide. All these documents indicate that the khrims were of practical use in legal cases. It is possible that some of the references could be to records of earlier decisions, which stood as precedents, or even to general principles-in one document non-Tibetans complain that they do not have the benefit of the $b k a^{\prime}$ khrims, seemingly a reference to Tibetan law in general. ${ }^{15}$ But it seems likely that most, if not all, of these khrims were written laws for judicial activity. They related to matters of both substance and procedure.

As van Schaik argues, the palaeographic style of the Dunhuang texts suggests that local scribes were making copies of central Tibetan documents for use in their region. ${ }^{16}$ This indicates some

Publications, 1998); Brandon Dotson, "Divination and law in the Tibetan Empire", Contributions to the Cultural History of Early Tibet, ed. M. Kapstein and B. Dotson (Leiden: Brill, 2007), "Introducing Early Tibetan Law: Codes and Cases", in Secular Law and Order in the Tibetan Highland, ed. D. Schuh (Andiast: IITBS, 2015); Fernanda Pirie, "Oaths and Ordeals in Tibetan Law", in Secular Law and Order, ed. D. Schuh, 177-95; and F.W. Thomas 1936, "Law of theft in Chinese Kan-su", Zeitschrift für Vergleichende Rechtswissenschaft, ed. E. Heymann et al. (Stuttgart: Verlag Ferdinand Enke, 1936). PT refers to the Pelliot tibétain collection in the Bibliotèque nationale de Fance; ITJ refs to Tibetan documents in the Indian Office collection of the British Library.

12 Dotson, "Divination and Law".

${ }^{13}$ Pirie, "Oaths and Ordeals".

${ }^{14}$ Dotson, "Introducing Early Tibetan Law".

${ }^{15}$ Dotson, op. cit. 306

${ }^{16}$ Sam van Schaik, "Towards a Tibetan Palaeography: Developing a Typology of Writing Styles in Early Tibet", in Manuscript Cultures: Mapping the Field, ed. Jörg Quenzer et al. (Berlin: De Gruyter, 2014). 
central control over regional practices. A long document contains replies to legal queries (the Replies document), ${ }^{17}$ and indicates that certain rules (in this case, the sho tshigs) needed to be applied by local officials under guidance from central authorities. Moreover, a section in the IDe'u Chronicles, written in the thirteenth century-which Dotson considers was based on lost imperial cataloguesrefers to wooden slips used at different stages of judicial processes and the taking of evidence from different parties. ${ }^{18}$ It is, therefore, evident that the Tibetan administration developed complex and systematic legal processes, over which a considerable amount of control was being exercised from the administrative centre of the regime.

A number of the Dunhuang documents relate to monasteries and their property, or to monks and nuns; and it is evident that several monasteries had become powerful institutions during the period to which these documents relate. However, there is no indication that the content of the khrims were, or were supposed to be, related to Buddhist texts or principles in any way. Niether judicial activity or the substance of the laws were explicitly linked to the ideas and texts of the new religion. ${ }^{19}$

Law, order, and government

The Annals provide a terse, practical account of imperial activities, and the rtsis $m g o$ and $b k a^{\prime}$ grims, which it says were made in the seventh century, appear to have been pragmatic administrative documents. We need to turn to the late eighth and early ninth centuries to find more ideological accounts of Tibetan politics and the nature of kingship. These emerge in a quite distinct set of inscriptions and texts, in which there is very little reference to law or judicial activity. It is also evident, as I describe in this section, that these accounts were not-at least initially-brought into line with Buddhist ideas about the qualities of the ideal king.

\footnotetext{
${ }^{17}$ ITJ 740 is discussed by Dotson in "Divination and Law" and "Introducing Early Tibetan Law".

${ }^{18}$ Brandon Dotson, Administration and Law in the Tibetan Empire: The Section on Law and State and its Old Tibetan Antecedents, D.Phil thesis (University of Oxford, 2006). The 'Section on Law and the State' appears in an expanded form in the sixteenth-century Feast for Scholars: dPa' bo gTsug lag Phreng ba, Dam pa'i chos kyi 'khor lo bsgyur ba ranms kyi byung ba gsal bar byed pa mkhas pa'i dga' ston (Beijing: Mi rigs dpe skrun khang, 1985). This has been the subject of detailed analysis by Geza Uray, "The Narrative of the legislation and Organization of the Mkhas pa'i dga' ston", Acta Orientalia Academiae Scientiarum Hungaricae, 26 (1972): 11-68.

${ }^{19}$ The use of the term 'religion' in Tibet is problematic. The evidence is that Tibetans of this period had a sense of distinctly Buddhist institutions and practices (sangs rgyas kyi chos), a term that appears in the Old Tibetan Chronicle: Jacques Bacot, F.W. Thomas, and C.-G. Toussaint, Documents de Touen-Houang relatifs a l'Histoire du Tibet (Paris: Librairie Orientaliste Paul Geuthner, 1940), 114. These are distinct from the general ritual or divine order (that of the Iha chos), which I describe in the next section. I use 'religion' to refer to the former.
} 
In the early days, the introduction of new religious practices was accompanied by the translation of a number of Buddhist texts. These included some that concerned the nature of government, notably Nagarjuna's Rin chen phreng ba (Precious Garland), translated in the early eighth century. ${ }^{20}$ In a section on the king, Nagarjuna emphasizes the moral qualities of the ideal ruler, which should include religious devotion and virtuous activities. He states that a ruler needs to treat offenders with compassion, not torture or death. Texts concerning the ten Buddhist virtues (dge ba bcu) also seem to have been translated or created during this period (van Schaik 2016: 20). ${ }^{21}$ These set out the activities that should not be undertaken by ordinary people: the three of the body (killing, stealing, and sexual misconduct), the three of the speech (lying, gossip, harsh speech, and slander), and the three of the mind (avarice, ill-will, and wrong views). Basic ideas concerning the nature of kingship and Buddhist morality were, therefore, described in Tibetan texts by the late eighth century.

At some point subsequent to his enthronement in 761 , Tri Srong Detsen issued a conversion edict, indicating his commitment to Buddhism. Here, he describes new religious practices in terms of moral conduct, the principles of re-birth, and the importance of temple founding. ${ }^{22}$ However, he does not relate the qualities of personal moral conduct directly to the activities of kingship. He refers to the ten virtues and ten non-virtues, but these are also not explicitly connected with the conduct of government. The edict records some initial fear on the part of the people that the new religious practices 'would threaten governance', but this was by bringing about epidemics, plague, and famine. ${ }^{23}$ Religious practices were regarded as having physical consequences for the realm and its people, that is, rather than providing guidance for the practice of kingship. In the 779 Tri Srong Detsen declared that Buddhism and its practices were to be the official religion of the realm. This was followed by the translation and circulation of further Buddhist texts. These included the Satyaha-parivarta, which has a chapter on royal ethics, described further below. By the early ninth

\footnotetext{
${ }^{20}$ Jeffrey Hopkins and Lati Rinpoche, eds, The Precious Garland and the Song of the Four Mindfulnesses (London: George Allen and Unwin, 1975). On this dating, see Michael Hahn, Nagarjuna's Ratnāvali, Vol 1, Basic Texts. (Bonn: Indica et Tibetica, 1982); Michael Zimmerman, "Only a fool becomes a king: Buddhist stances on punishment", in Buddhism and Violence, ed. M. Zimmerman (Lumbini: International Research Institute, 2006), 228; and Jonathan Silk, "The Proof is in the Pudding", Indo-Iranian Journal 56 (2013): 157-78, 158. Dunhuang documents also contain portions of the text.

${ }^{21}$ Sam van Schaik, The Spirit of Tibetan Buddhism. (London: Yale University Press, 2016), 20.

${ }^{22}$ Matthew Kapstein, "The Adoption of Buddhism and the Foundation of Samyé Monastery: The Conversion Edict of Tri Songdetsen", in Sources of Tibetan Tradition, ed. K.R. Schaeffer et al. (New York: Columbia University Press, 2013), 60-64.

${ }^{23}$ ibid, 62.
} 
century, under the emperor Ralpachan, texts on the ten virtues were being widely circulated..$^{24}$ It is not apparent, however, that the ideas in these texts had any influence on Tibetan accounts of their own kingship, let alone their practices or ideas about law.

Eulogies to the emperors are found in several texts from the early ninth century. In the accounts of their achievements and the greatness of their realm, the rulers are described as forming a link between heaven and earth. This is in line with indigenous traditions that long predated the introduction of Buddhism. ${ }^{25}$ Two concepts recur in these accounts, gtsug lag, (imperial) power, capacity, or order, and chos bzang, good customs or practices, which some scholars have read as referring to Buddhism and Buddhist practices. However, as I describe here, others have convincingly argued for non-religious readings of these important, but contentious, terms. The pillar inscription from the tomb of Tri Song Detsen, for example-made after his death at the turn of the eighth and ninth centuries-refers to chos gtsug lag. ${ }^{26}$ The emperor is presented as following the customs (lugs) of his ancestors, not disturbing the divine order (/ha'igtsug lag), and acting in accordance with the traditions of heaven and earth (gnam sa'i chos). A later pillar inscription records the treaty entered into by Tibet and China in around 821 , following a period of conflict between them. ${ }^{27}$ It presents the great order or great powers (gtsug lag chen po) of the emperors, the benevolence and harmony that resulted, and the way in which they subdued their enemies and increased their dominions. The emperors also made chos khrims, and by these means, 'they set right the ways of men' (myi'i lugs). This seems to be indicating that the rulers were responsible for good conduct (chos khrims) on the part of their subjects. There is no particular reason to link these concepts with distinctly Buddhist ideas or practices.

A long document (PT 16/ITJ 751) presents prayers associated with the founding of the temple of Dega Yutsel (De ga g.yu tshal), which formed part of the Sino-Tibetan treaty events. ${ }^{28}$ The founding

\footnotetext{
${ }^{24}$ van Schaik, The Spirit of Tibetan Buddhism, 61-62.

${ }^{25}$ Brandon Dotson and Matthew Kapstein, 2013. "The Old Tibetan Chronicles", in Sources of Tibetan Tradition, ed. K.R. Schaeffer et al. 36-46, 41.

${ }^{26}$ Hugh Richardson, "A New Inscription of Khri Srong IDe brtsan", Journal of the Royal Asiatic Society 1/2 (1964): 1-13.

${ }^{27}$ Hugh Richardson, A Corpus of Early Tibetan Inscriptions (London: Royal Asiatic Society, 1985), 10643; Fang Kuei Li and W. South Coblin, A Study of Old Tibetan Inscriptions (Taipei: Academia Sinica, 1987), 134-37.

${ }^{28}$ Matthew Kapstein, "The Treaty Temple of the Turquoise Grove", in Buddhism between Tibet and China, ed. M. Kapstein (Boston: Wisdom Publications, 2009), 21-72. Walter argues that the document is a later compilation of imperfectly transcribed imperial texts: Michael L. Walter, "Analysis of PT016/IO751-Language and Culture of a Dunhuang document, part one" in Tibet after Empire: Culture, Society and Religion between 850-1000, ed. C. Cüppers et al. (Lumbini: International Research Institute, 2013), 417-40. It must, therefore, be treated with some caution.
} 
of a monastery to mark a political treaty indicates a nexus between politics, diplomacy, and religion, but as in the case of the edicts referred to earlier, the religion is represented by its institutions, rather than a source of ideas concerning government and order. The prayers refer to the notions of chab srid (government), chos gtsug (established practices, maybe), chos bzang and lugs kyis bzang (good practices), and gtsug lag che (great power or order). A reference to Iha chos gtsug lag bzang po seems to indicate good, established ritual activities (Iha chos). The document also records that the emperors tamed the high and encouraged the low. These prayers, then, give an account of the good qualities of the Tibetan rulers and the great order that they established. ${ }^{29}$ But there is no reason to connect any of these ideas directly with Buddhism. It is notable, moreover, that there are no references to khrims in this document. This indicates that the authors did not regard law or lawmaking as particularly potent symbols of imperial greatness or, indeed, as the foundation of the good order of their realm.

An even more lengthy eulogy to the early emperors is found in the Old Tibetan Chronicle, which seems to have been written in the $840 \mathrm{~s} .{ }^{30}$ Here, the early emperors are again presented as forming a link between heaven and earth. As good rulers, and in contrast to the bad, they are said to have recognised the good and wise and those who were truthful and courageous; they improved people's welfare, expanded borders, increased wealth, and secured loyalty. Later emperors-Tri Du srong (Khri 'Dus Srong), and Tri Song Detsen-are credited with chos bzang (good practices) and gtsug lag (governmental power or order). Under Tri Song Detsen, the text says, there were chos bzang srid che (good customs and great government) and by the gtsug lag chen po (great power or order) the ruler obtained sovereignty over men and beasts. As for the chos, it continues, the ministers acted correctly. The text records that during his reign the practices of Buddhism, sangs rgyas kyi chos, were introduced or officially affirmed. However, this act is not presented as the basis for the good customs and great government of the era. The implication is that these were already established. Following the account of Tri Srong Detsen, the narrative goes back to the earlier king, Songtsen Gampo (Srong btsan sgam po), who is said to have been responsible for chos bzang (good customs)

Nevertheless, the terms used probably reflect the ideas in cirulation at the time of the templefounding.

${ }^{29}$ Kapstein, "The Treaty Temple", 33-34.

${ }^{30}$ Bacot et al. Documents de Touen-Houang; Dotson and Kapstein, "The Old Tibetan Chronicles". The date of this document is uncertain, but the events continue to Langdarma (gLang dar ma), suggesting that it was composed in, or after, the $840 \mathrm{~s}$. It has been suggesed that it is a later compilation, possibly dating from the eleventh century, of earlier texts: Christopher I. Beckwith and Michael L. Walter, "Dating and Characterization of the Old Tibetan Annals and The Chronicle", in From Bhakti to Bon: A Festschrift for Per Kvaerne, ed. H. Havnevik and C. Ramble (Oslo: The Institute for Comparative Research in Human Culture, 2015), 53-88, 82. 
and srid mtho (lofty government). After introducing writing, it says, he made a Tibetan gtsug lag $b k a^{\prime}$ khrims ched po, a great legal and administrative edict; thereby, he established Tibetan chos kyi gzhung bzang po kun, good traditions of behaviour. This seems to be a reference to the $b k a^{\prime}$ grims kyi yi ge of the Annals, which is now being attributed to the earlier emperor, Songtsen Gampo.

There has been considerable debate about the meaning of the concepts chos bzang and gtsug lag, which I have been translating as 'good customs or practices' and 'good power or order'. Stein, among many others, maintained that chos lugs bzang po refers to Buddhist practices. More recently, however, van Schaik has convincingly argued that in the imperial period the concept of chos referred to customs and practices in general. ${ }^{31}$ It may have suggested prescribed behaviour, but it was not particularly related to religious or ritual practices or doctrine. As regards gtsug lag, Stein suggests that it indicates wisdom, art, or science, and Kapstein largely agrees, arguing that it refers to the special capacity of the monarch to bring proper order to his subjects or the wisdom of just rulership. ${ }^{32}$ Hahn, following Macdonald, has been inclined to understand it in more religious terms, maintaining that gtsug lag means worldly wisdom, as proclaimed by the Buddha, or tradition reaching back to his time, while Walter argues strongly that it refers to power with distinctly Buddhist connotations. ${ }^{33}$ However, van Schaik's arguments with respect to chos apply equally to gtsug lag. There is no particular reason to associate this concept with religious ideas and practices, save where it is used in compound phrases, such as Iha'i gtsug lag-the order of the deities. Like sangs rgyas kyi chos, practices of Buddhism, the addition of the adjectives Iha or sangs rgyas indicates that when used on their own, as they more often were, the concepts of gtsug lag and chos had no such religious connotations. I would also suggest that, rather than referring to the capacity and wisdom of the emperors, gtsug lag could also be read as referring to the overall order of the realm, for which they are responsible. It indicates what it is that the rulers have established, gtsug. While chos refers to customs and practices, that is, gtsug lag has a sense of overall order. ${ }^{34}$

${ }^{31}$ R.A. Stein, "Tibetica Antiqua III: A propos du mot gcug-lag et de la religion indigène", Bulletin de I'Ecole française d'Extrême-Orient 74 (1985): 83-133; Sam van Schaik, "The naming of Tibetan religion: Bon and Chos in the Tibetan imperial period", Journal of the International Association for Bon Research 1 (2013): 227-57.

32 Kapstein, Tibetan Assimilation, 55, n. 27; The Tibetans, 45-46; "The Treaty Temple", 33, n. 57.

${ }^{33}$ Michael Hahn, "A Propos the Term gTsug Lag", in Tibetan Studies, ed. H. Krasser et al. (Wien: Verlag der Österreichischen Akademie der Wissenschaften, 1997); Ariane Macdonald, "Une lecture des P.T. 1286, 1287, 1038, 1047, et 1290. Essai sur la formation et l'emploi des mythes politiques dans la religion royale de Sron-bcan sgam-po", in Études tibétaines dédiées à la mémoire de Marcelle Lalou (Paris: Librairie d'Amérique et d'Orient, 1971), 190-391; Michael L. Walter, Buddhism and Empire: The Political and Religious Culture of Early Tibet (Leiden: Brill, 2009), 225-30.

${ }^{34}$ This is most clearly indicated in the Old Tibetan Chronicle. However, whether gtsug lag is to be understood as power, capacity, or order does not substantially affect the arguments of this paper. 
If it is right that these concepts did not have specifically religious connotation during this period, then in all the accounts discussed here, the imperial order is not connected, in any significant way, with the moral ideas of Buddhism. The emperors patronized the new religion, they founded temples and monasteries, and practised new death rituals. These activities were important-and controversial-in and of themselves. However, neither the ritual practices nor, more significantly, Buddhist morality, were regarded as being foundational to the existence of the good order and excellent customs of the realm. The sangs rgyas khyi chos (practices of Buddhism) had not yet become central to the account that Tibetan writers were creating about the greatness of their realm and the excellence of their rulers' activities. Up to the mid ninth century, that is, ideological accounts were not presenting the imperial order in terms of the ideas offered by the new religion. The nexus between Buddhism and politics was found primarily in the realm of temple-founding and the associated ceremonies and rituals.

As regards law, it is only the Old Tibetan Chronicle, among these texts, that sees fit to mention the making of a legal edict. This is said to follow the introduction of writing by Songtsen Gampo and seems to be a reference to the legal code mentioned in the Annals. In practice, as described above, the khrims (or grims) were primarily rules for punishment, compensation, and judicial procedure. As such, they were part of the practical business of administration, which did not merit particular attention in these more ideological accounts. Our sources from this period on the making and practice of law and those in which the activities of the rulers are described and extolled are almost entirely different.

\section{Buddhism and law}

Some of the Indian texts translated into Tibetan in the eighth and ninth centuries presented a vision of the moral, Buddhist king, and at some point Tibetan writers began to make connections between Buddhism and law. This is primarily evident in texts from around the mid ninth century. As already mentioned, Nagarjuna's Rin chen phreng ba, translated in the early eighth century, had expressed moral disapproval of rulers who impose a harsh legal regime on their subjects. The Satyahaparivarta, a sutra probably translated in the early ninth century, also contains an elaborate account of royal ethics..$^{35}$ It criticizes some of the Indian arthaśāstra literature, with its vision of heroic military kingship, it rejects capital punishment, advocates improvement and rehabilitation for offenders, and stresses the need for rulers to cultivate compassion. We do not know how widely the text circulated during this period, however. The Indian master, Buddhaguhya, is said to have written

\footnotetext{
${ }^{35}$ The full title is the Bodhisattva-gocaropāya-visaya-vikurvana-nirdesa-sutra: Zimmerman, "Only a fool becomes a king".
} 
a letter directly to Tri Srong Detsen, containing advice for the ruler about how he should act as a good Buddhist king. Its historical introduction describes Tibet as having being pacified-or the people having been converted ( $d u l b a)$-by his ancestors, through the laws of the ten virtues (dge bcu thang khrims). ${ }^{36}$ However, as Karmay points out, parts of the text refer to later events, so it may well date from a later period. ${ }^{37}$

A somewhat obscure Dunhuang document, PT 100, is linked by Stein to the text concerning the founding of Dega Yutsel, discussed above (PT 16/ITJ 751)..$^{38}$ It contains a reference to tshul khris, which Stein interprets as tshul khrims, indicating a set of rules for monastic conduct. It also refers to gthan khrims zab mo dge ba bcu'i rtsa ba, the excellent laws that were the roots of the ten virtues. The provenance and significance of this text are not at all clear, but it does indicate that links were being made between the khrims and the dge ba bcu by the middle of the ninth century. Further Indic influence is indicated by a letter written by Pelyang (dPal byangs), a Tibetan master, which probably dates from around the same period. ${ }^{39}$ An early section describes, in some detail, the ten virtues and the sixteen mi chos-rules for moral conduct-almost certainly drawing on Indian precedents. ${ }^{40}$ The document continues with a section containing advice to the king and directs that he should make khrims to protect the dam chos, the excellent religion. ${ }^{41}$ This is a case of laws being made to protect the religion and its institutions, rather than enshrining religious principles in rules for conduct or principles of governance.

These texts indicate that by the mid ninth century Indian Buddhist ideas about kingship were available to Tibetans. Moreover, at least some writers were making an explicit link between the rulers' activities and laws, on the one hand, and the moral principles of Buddhism, on the other. However, as we have also seen, the major imperial eulogies written during this same period place little emphasis on the creation of khrims in relation to the administrative and legal achievements of the emperors. Practical legal documents, moreover, are devoid of references to Buddhist principles and moral ideals.

What does this tell us about the introduction of Buddhism and the influence of its various

\footnotetext{
${ }^{36}$ Siglinde Dietz, Die Buddhistiche Briefliteratur Indiens, (Wiesbaden: Otto Harrassowitz, 1984).

${ }^{37}$ Samten Karmay, The Arrow and the Spindle: Studies in History, Myths, Rituals, and Beliefs in Tibet, vol 1 (Kathmandu: Mandala Book Point, 1998), 25.

${ }^{38}$ R.A. Stein, "Tibetica Antiqua IV: La tradition relative au début du Bouddhisme au Tibet", Bulletin de I'Ecole francaise d'Extreme-Orient 74 (1986), 169-96, 178.

${ }^{39}$ Dietz, Die Buddhistiche Briefliteratur Indiens.

${ }^{40}$ Ulrike Roesler, "'16 Human Norms' (mi chos bcu drug) -Indian, Chinese, and Tibetan", in The Illuminating Mirror ed. O. Czaja and G. Hazod (Wiesbaden: Dr. Ludwig Reichert Verlag, 2015).

${ }^{41}$ This is an addition to the Indian text, the Kaniskalekha of Mātrceta, on which this section is based.
} 
practices, texts, and ideas on the administration of the Tibetan empire? As Kapstein and van Schaik argue, the adoption of Buddhism almost certainly made the symbols of a universal civilization available to Tibetan rulers. ${ }^{42}$ We should not underplay the importance of Tri Song Detsen's conversion, the activities of temple-founding that followed it, the introduction of new rituals, and the invitation of monks and Buddhist teachers. Nor should we under-estimate what the introduction of the idea of karma, re-birth, may have meant in personal terms. Nevertheless, there is no evidence that the notion of karma provided a model for legal practices. Nor does it seem that the idea of the ten virtues or the moral norms of kingship expounded by Nagarjuna and others had any direct impact on Tibetan legal practices, or on indigenous accounts of the imperial order.

We do not have to wait too long, however, to see these ideas being more firmly brought together in new historical accounts. This seems to have taken place just as the structures of the empire were beginning to crumble.

\section{Turmoil and ideological change}

From around the 840 s, the empire was rocked by internal power struggles and its administrative structures had practically disappeared by the early tenth century. ${ }^{43}$ In the following decades political organisation was fragmented, at best, and there was considerable challenge to the major Buddhist institutions and practices. Nevertheless, it was around the monasteries, scholars, and texts of Buddhism that new political structures eventually coalesced. This period also saw major developments in ideas and ideologies about law, government, and religion. Maybe surprisingly, law came to be presented as much more important within the narratives concerning the founding of the Tibetan empire and civilization, just at the time that its administrative and judicial structures were collapsing.

\section{The Scripture from the Sky}

A shift towards a more explicitly Buddhist account of the (now disintegrating) empire is marked by ITJ 370, referred to as the Dharma from Heaven by Richardson. ${ }^{44}$ Its importance in marking a shift in

\footnotetext{
${ }^{42}$ Kapstein, The Tibetans; van Schaik, Tibet: A History.

${ }^{43}$ Kapstein, The Tibetans, 77-83; van Schaik, Tibet: A History, 46-50.

${ }^{44}$ Hugh Richardson, "The dharma that came down from heaven", in Buddhist Thought and Asian Civilization, ed. L. Kawamura and K. Scott (Emeryville: Dharma Publishing, 1977). van Schaik suggests that the dam ma in the opening line is better read as a 'scripture', hence Scripture from the Sky: Dharma from the Sky III: Self-Appointed Buddhas (earlytibet.com/2010/09/24/dharma-from-the-skyiii/).
} 
ideas has already been noted by Stein and Kapstein. ${ }^{45}$ However, van Schaik's placing of the text in the second half of the ninth century, or even later, sheds new light on its implication for the assimilation of Buddhist ideas. ${ }^{46}$ The text preserved at Dunhuang is a partial draft of what must have been a longer document, and gives a brief account of the activities of the early emperors. It contains similar ideas to those of the Old Tibetan Chronicle, referring to the making of chos and gtsug lag. These are now attributed to the receipt of a scripture, which falls from the sky. A peaceful kingdom, characterized by moral behaviour, results. The rgyal khrims, royal laws, are made by protective kings (myi mgon), an indication of a good realm, along with the path of truth, the practice of the ten virtues (dge ba'i chos), and the advice of wise forebears.

This text presents a subtly different picture of Tibetan history to that of the Old Tibetan Chronicle. The central concepts are still gtsug lag and chos (governmental order and customs). However, instead of being attributed to the activities of great rulers, who formed a link between heaven and earth, the imperial order is now attributed to the receipt of a scripture from the sky. Moreover, as the remainder of the text makes clear, this scripture is a Buddhist one. The excellence of the realm is characterized by the path of truth and the discipline of the ten virtues, distinctly Buddhist ideas, and the text continues with a discussion of different types of ritual practices, seeming to distinguish between proper and improper. This indicates a new concern with the correctness of religious practice and its importance to the establishment and maintenance of good order. The text, therefore, represents a shift in the accounts that Tibetan writers were presenting of the history of their realm. Ideas attributed to the new religion - the texts of its doctrine, the path of truth, and the discipline of the ten virtues-are now being brought together with older accounts of imperial order and excellent custom. The khrims are part of this picture, although they are just one characteristic of a good (imperial) realm, the work of a protective king. The making of the laws is not yet presented as a means to embody or promote religious morality, or the order that results from the receipt of the doctrine.

Of course, we do not know how important this document was at the time it was written. However, the fact that it was being copied at Dunhuang suggests that it was significant. In any event, it contains ideas that we find in later narrative accounts and clearly marks the development of new ideas. Before turning to other narrative accounts, the following section describes some of what we know about practical politics and law-making during this period.

The activities of Yeshe Öd

\footnotetext{
${ }^{45}$ Stein, Tibetica Antica III, 173-80; Kapstein, Tibetan Assimilation, 57-58.

${ }^{46}$ van Schaik, op. cit.
} 
There is little clarity about this period of Tibetan history: there was obviously conflict within the ruling dynasty, political fragmentation, and loss of control over outlying areas, including Dunhuang. There was also a multiplication of ritual practices, over which tantric practitioners came to acquire considerable influence. This was a concern to Yeshe Öd (Lha bla ma ye shes 'od), an important figure who briefly ruled Ngari ( $m N g a^{\prime}$ ris), in Western Tibet, in the late tenth century. ${ }^{47}$ His efforts to control religious practices and centralize political power are indicated by both contemporary edicts and later historical accounts. ${ }^{48}$ The most detailed source is his biography, written four centuries later, in around 1480, by Drakpa Gyaltsen (Grags pa rgyal mtshan). As a historical account, the content and style of this biography must have been influenced by the writer's own background and context. However, it seems that he lived and worked in the monastery of Tholing, founded by Yeshe Öd, and probably had access to original sources. Moreover, the biography does not contradict contemporary edicts. ${ }^{49}$

In this account khrims are prominent. They are central to the activities of the ruler, the protection of religious institutions, the maintenance of peace, the moral conduct and happiness of the people, and the correct behaviour of monastics. Yeshe Öd, himself, is said to have created laws and presented them to a great assembly. He is also recorded as giving repeated instructions to his successors about how laws should be created and followed. Yeshe Öd took monastic vows after a relatively short period as ruler and several sections of the biography describe or reflect the advice he gives to his successors concerning practices of good governance. He says that a ruler must ensure that power is not fragmented and is exercised in accordance with the former royal laws (rgyal khrims); edicts must be made to ensure that religious establishments and their inhabitants are supported and the doctrine is spread; those who break the law must be punished appropriately;

\footnotetext{
${ }^{47}$ Gu ge Pandita Grags pa rGyal mtshan, Lha bla ma Ye shes 'Od kyi rnam thar rgyas pa bzhugs so, ed. Do rgya dbang grag rdo rje (Lhasa: Bod ljongs mi dmangs dpe skrung khang, 2013).

${ }^{48}$ Samten Karmay, "The Ordinance of Lha Bla-ma Ye-shes-'od", in Tibetan Studies in Honour of Hugh Richardson, ed. M. Aris and Aung San Suu Kyi (Warminster: Aris and Phillips, 1980), 150-62; Roberto Vitali, The Kingdom of Gu.Ge Pu.Hrang According to Mnga'.Ris Rgyal.Rabs by Gu.Ge Mkhan.chen Ngag.Dbang Grags.Pa (London: Serindia, 1997).

${ }^{49}$ Jacob P. Dalton, "Power and Compassion: Negotiating Buddhist Kingship in Tenth-Century Tibet", in The Illuminating Mirror, ed. Olaf Czaja and Guntram Hazod (Leiden: Brill, 2015), 102 .The accounts of law and law-making found in this text do not display any obvious influence from narratives about law that were well-known in the fifteenth century, such as those of the Ma ni bka' 'bum or the rGyal rabs gsal ba'i me long. In these narratives, laws introduced by Songtsen Gampo were based on the ten virtues. While the references to law in Yeshe Öd's biography are not inconsistent with this idea, and Yeshe Öd refers to the laws of his ancestors, there is no reference to Songtsen Gampo, or to the ten virtues. The biographical account does, therefore, seem to be based on historical documents. With this caveat, we can read it as an account of events that occurred during this period and the ideas and activities that Yeshe Öd considered to be important.
} 
literacy and virtue must be promoted, and so on (fols 13a-14b, 31a-32a, 33b-34b, 35a-b). When it comes to law-making, Yeshe Öd says that rulers should respect the ancient laws of their forebears and the advice found in Indian texts, as well as his own, more recently-created, laws (fol. 26a). ${ }^{50}$ Law-making is now central to the activities of a good ruler, and the foundation of peace and order. Moreover, more than just pragmatic judicial rules-as they largely were in the empire-the laws are presented as enshrining moral principles, for which rulers should look to Indian texts.

The biography indicates that different laws were made for different people. On the one hand, the chos khrims, tshul khrims, and dge 'dun gyi khrims seem to refer to rules (of discipline) for monastics. On the other hand, there are more general khrims lugs or khrims yig for the laity (see, for example, fol. 30b). As Dalton convincingly argues, the text clearly distinguishes the spheres of monastic and secular activity. There is a sense of two distinct realms, with their own rules for conduct. ${ }^{51}$ At the same time, the separation between the two realms should not be overemphasized. Lay people were also expected to engage in religious practice and the text makes it clear that the general khrims should guide them towards virtuous conduct (fols 30a-b, 33b-35b). Yeshe Öd also emphasizes that the ruler's khrims need to be respected by monastics (fols $25 a-b$ ). All law, that is, has broadly moral and religious purposes.

New ideas about law and order and their relationship with religious morality do, that is, seem to have shaped the practices of at least one Tibetan ruler by the late tenth century. In terms of the concepts used in this text, the gtsug lag, the imperial order of earlier writings, now seems to have taken on specifically religious connotations: the gtsug lag khang are Buddhist temples. At the same time, the concept of chos has come to be much more closely associated with religious practices and institutions than conduct in general. ${ }^{52}$ In their place, the concept of khrims and, to a lesser extent, lugs have become more central to the administrative order established by the ruler. The realm of a good ruler is characterized by the making of good khrims. There is also a difference in the emphasis of the ruler's achievements. In the Old Tibetan Chronicle the emperors were credited with an expanding domain, physical security, and the happiness of the people. Here, there is a greater emphasis on the promotion of moral behaviour and correct religious practice.

Compared to the imperial documents referred to above, this text reflects the concerns of a ruler

\footnotetext{
${ }^{50}$ Dalton, "Power and Compassion", 106-07.

${ }^{51}$ The writer uses the phrase lugs gnyis (two systems) - religious and political-although this may be a later gloss. The concept of chos khrims, here relating specifically to monastics, is almost certainly different from that of the Sino-Tibetan treaty pillar inscription, which seems to refer to good customs, in general.

${ }^{52}$ For example, there are references to chos rtsigs, religious works, and chos 'khor, religious establishments (fols 33b, 34a).
} 
seeking to establish order in an unstable and much more local setting. The administrative structures of the empire have by now largely disintegrated, religious practices have multiplied, and both religious and secular authority have become fragmented. The main concerns of Yeshe Öd are the suppression of Bön and other dubious ritual practices. The text indicates an overwhelming focus on support for the proper religion, its practitioners, and establishments. Nevertheless, Yeshe Öd is also concerned about political unity in western Tibet and is keen to re-establish something of the good order of the great emperors of the past. ${ }^{53}$ The khrims are now the main instrument through which this is to be achieved and they consist of rules for correct religious practices and good moral conduct.

The khrims occupy a very different, and more prominent, place within this ruler's vision of the order of his realm than they did in imperial times. We should probably assume that by the late tenth century, the management of conflict and disputes had become very localized, as the centralized judicial system of the empire disintegrated. Maybe local mediators and power-holders continued to refer to the former laws and procedural rules, but the biography does not indicate that any processes with the complexity of the imperial system were still being undertaken. The khrims are rules for good, moral, conduct, rather than laws that specify amounts of compensation, distinguish types of offence, and make procedural rules for litigation. It is as if the disintegration of a centralized system of justice paved the way for the presentation of khrims as rules for general behaviour, with much more moral and religious orientation.

\section{The emergence of an ideology}

As Kapstein, describes, with the fall of the empire in the ninth century, Tibetans were faced with a practical and political crisis. ${ }^{54}$ In this context, the cosmology and soteriology of Buddhism provided a way of making sense of the world around them. While Yeshe Öd emphasized that rules for moral conduct should form the basis for the good order of his dominions, Tibetan historians were creating a more elaborate, and lasting, account of a political domain based on Buddhist principles.

\section{The $d B a^{\prime}$ bzhed}

The ' $\mathrm{Ba}$ (or sBa) clan provided influential ministers during the empire and their descendants wrote a chronicle to record their activities between the ninth and twelfth centuries. Several different versions survive, and there is considerable uncertainly over their dates: parts of the $d B a^{\prime}$ bzhed date

\footnotetext{
${ }^{53}$ Fol. 26a; Dalton, "Power and Compassion", 106-07.

${ }^{54}$ Kapstein, Tibetan Assimilation, 36-37.
} 
back to the Dunhuang period (van Schaik and Iwao 2008). ${ }^{55}$ However, the account was almost certainly elaborated upon later. Kapstein (2000: ch. 2) has described the importance of this text in the elaboration of the Tibetan's new vision of their history. Here, I concentrate on the references to law.

All versions of the chronicle concentrate on the time of Tri Srong Detsen, but the $d B a^{\prime}$ bzhedthe earliest version-also contains a section that describes events under Songtsen Gampo and attribute him with the making of Tibet's first laws (Pasang Wangdu and Diemberger 2000: 237-39). Following the receipt of religious texts by his ancestors, which drop from heaven in a casket, the king sends his minster, Tonmi Sambhota, to India so that he can learn how to read the texts and create a suitable script for Tibet. The minister brings back a text of the ten virtues and, after reading it, Songtsen Gampo creates his own laws (rgyal khrims). These laws concern the giving of blood money for homicide, compensation for theft, and mutilation for sexual misconduct. ${ }^{56}$ They are announced to the people, along with a rtsis mgo, an administrative plan, and chos lugs bzang po, rules for good behaviour, and he gives strict instructions about the observation of the laws.

The references to the rtsis mgo and chos lugs recall the terminology of the Annals, Tri Song Detsen's tomb inscription, and other imperial eulogies, ${ }^{57}$ and in substance, the story resonates with the Annals and Dunhuang documents. An early emperor creates a $b k a^{\prime}$ grims after the introduction of writing and there are laws concerning killing, injury, and theft. The attribution of this activity to Songtsen Gampo follows the reworking of history found in the Old Tibetan Chronicle. However, the direct association of law-making with the ten virtues is new. There also a reference in this text to the chos khrims. These are said to have been 'retied' during the rein of Ralpachan, suggesting the reaffirmation of Buddhist practices after an interruption-probably events that took place under his immediate predecessors at the turn of the eighth and ninth centuries. ${ }^{58} \mathrm{As}$ in the biography of Yeshe Öd, this indicates a distinct form of khrims, rules for ritual or monastic activity. In later histories rgyal khrims and chos khrims, royal and religious laws, are regularly presented as distinct, but

\footnotetext{
${ }^{55}$ Sam van Schaik and Kazushi Iwao, "Two fragments of the Testament of Ba from Dunhuang", Journal of the American Oriental Society 128, issue 3 (2008), 477-87. The $d B a^{\prime}$ bzhed text can be found in Pasang Wangdu and Hildegard Diemberger, $d B a^{\prime}$ bzhed (Wien: Verlag der Osterreichischen Akademie der Wissenschaften, 2000). The text of the later $s B a$ bzhed, referred to here, is that published by R.A. Stein, Une chronique ancienne de bSam yas: sBa bzed (Paris: Publications de l'institute des hautes études chinoises, 1961).

${ }^{56}$ These details are contained in an addition to the manuscript. As Pasang Wangdu and Diemberger point out $\left(d B a^{\prime}\right.$ bzhed, p. 11), the origin of the several interlinear additions is difficult to ascertain.

${ }^{57}$ Pasang Wangdu and Diemberger (op. cit.) note that the text contains several other examples of distinctively early terminology.

${ }^{58}$ Pasang Wangdu and Diemberger, op. cit. 274.
} 
complementary.

Although the date of its composition is uncertain, this account marks the development of a set of new ideas in Tibet, whereby law-making and the receipt of Buddhist texts from India are explicitly equated. Moreover, this act has now become foundational to the establishment of the great imperial order. The making of khrims has replaced the gtsug lag, in this regard, and is equated firmly with the receipt of a text of the ten Buddhist virtues. Two sets of laws, the rgyal khrims and the chos khrims, are now the basis for good (moral) conduct on the part of the general population and those who have taken monastic vows, respectively. The stage is set for the account of Buddhist law that is elaborated in later narratives. The twelfth-century $b K a^{\prime}$ chem $\mathrm{ka} \mathrm{khol} \mathrm{ma,} \mathrm{for} \mathrm{example,} \mathrm{repeats} \mathrm{the}$ account of Songtsen Gampo's law-making and refers repeatedly to the royal and religious laws (rgyal khrims and chos khrims), sometimes likening them to a single sun, while similar accounts are found in Nyangrel's Me tog snying po sbrang rtsi'i bud and the Ma ni bka' 'bum, from the same period, and in later texts.

A tension is, however, apparent in the $d B a^{\prime}$ bzhed, which also runs through later accounts. The ten virtues of Buddhism are presented as the basis for new laws, but they are hardly an appropriate basis for practical social regulation. While the first three-concerning killing, stealing, and sexual misconduct-are presented in terms of laws concerning punishment and compensation, it is difficult to see how any laws might effectively regulate such things as gossip, avarice, and wrong views. Indeed, the addition to the text that describes the nature of the new laws does not descend into specifics in this regard. So, are the rgyal khrims practical rules for judicial processes and dispute resolution, or are they directions for moral conduct, through which basic principles of Buddhist morality are explained to the general population?

There is also the problem of punishment. The addition describes mutilation as the punishment for sexual misconduct. However, later in the text it is said that Tri Song Detsen made a $b k a^{\prime}$ shog, an official decree, forbidding mutilation punishments, at the same time as ordering that the great (religious) doctrine and precepts be bestowed on the people. ${ }^{59}$ This later passage might be read as an imperfect attempt by the writer (or one of several writers) to reconcile the Buddhist idea of nonharm with the actual traditions of Tibetan law-making. As already mentioned, Nagarjuna's Precious Garland directs that the ruler should deal with offenders through compassion, not torture or death, and the Satyaha-parivarta advocates improvement and rehabilitation for offenders. In the $s B a$ bzhed, almost certainly written after the $d B a^{\prime} b z h e d$, it is said that Tri Srong Detsen makes a $b k a^{\prime}$ sho and chos khrims forbidding mutilation punishments and the execution of wrong-doers. ${ }^{60}$ This

\footnotetext{
${ }^{59}$ Pasang Wangdu and Diemberger, op. cit. 262

${ }^{60}$ Stein, Une chronique, 45.
} 
indicates the same concern to make Tibetan law seem more Buddhist. It is possible that the writers were reinterpreting Tri Song Detsen's declaration of an amnesty, $b k a^{\prime}$ sho, as a change in rules for punishment. With the demise in commercial activity and fragmentation of political power, the granting of debt amnesties, often grand gestures of imperial mercy, had probably come to seem anachronistic. If this is right, it is further indication that Tibetan writers were putting a more Buddhist gloss on imperial activities. ${ }^{61}$ This shift towards a more Buddhist presentation of law resonates with a change that Mills has noted in the story of the monks from Khotan, found in this and later narratives. ${ }^{62}$

The $d B a^{\prime}$ bzhed, then, contains a mix of ideas that are not entirely consistent. It indicates that Tibetan writers were facing some difficulty in developing a satisfactory account of Buddhist law, one that could reflect Tibet's historical traditions, conform to the ideas found in Buddhist texts, and also match contemporary practices. Subsequent narratives continue to list execution and mutilation among the punishments ordained in Songtsen Gampo's initial laws, although others present more idealized accounts. In the twelfth century Ma ni bka' 'bum, for example, the royal laws merely involve the punishment of emanations, in order to frighten people into good behaviour. ${ }^{63}$ Uniting historical traditions with the ideas found in Buddhist texts was, that is, a challenge. To a large extent, this reflects a problem with which Indian writers had already wrestled. ${ }^{64}$ As van Schaik points out, there is nothing new in warlike rulers adopting Buddhism, despite the apparent ideological contradictions it entailed. ${ }^{65}$ However, it did present a problem for Tibetan writers. What Zimmerman describes as the practical synthesis of the Satyaha-parivarta, which emphasizes the compassionate

\footnotetext{
${ }^{61}$ As I have argued elsewhere (http://tibetanlaw.org/node/19), references to $b k a^{\prime}$ sho in early Tibetan documents indicate that the emperors periodically granted debt amnesties, presumably to grant some relief to impoverished peasants and merchants. Dotson suggests that the reference in the sBa bzhed is evidence of the granting of an amnesty: "Introducing Early Tibetan Law", 283. However, as I suggest here, it looks more like a reinterpretation of imperial practice. The granting of an amnesty gives relief to some people from the rigours of the law, while the edict described in the $s B a$ bzhed involves a permanent change in the law.

${ }^{62}$ Martin Mills, "Ritual as History in Tibetan Divine Kingship: Notes on the Myth of the Khotanese Monks", History of Religions 51 (2012), 219-20, 233-35

${ }^{63}$ A Collection of Rediscovered Teachings Focussing upon the Tutelary Deity Avalokiteśvara (Mahākarunika), reproduced from a print from the no longer extant Spuns-than blocks, ed. Trayang and Jamyang Samten (New Delhi, 1975). These accounts are found in several later narratives. I have summarized the ways in which they deal with this issue elsewhere (http://tibetanlaw.org/node/21), but a detailed discussion is beyond the scope of this paper.
}

${ }^{64}$ Zimmerman, "Only a fool becomes a king".

${ }^{65}$ van Schaik, "Towards a Tibetan Palaeography", 39. 
purposes of punishment, does not appear in the $d B a^{\prime}$ bzhed. ${ }^{66}$ Rather, we see Tibetan writers engaged in their own projects of combination and reconciliation.

Despite these difficulties, the basic idea that Songtsen Gampo had created Tibetan law on the basis of the ten Buddhist virtues took hold. It was repeated and embellished in a long tradition of historical narratives, from the $b K a^{\prime}$ chems ka khol ma onwards. An idea of Buddhist law had been born.

\section{Conclusion}

The idea that the early Tibetan king, Songtsen Gampo, affirmed Buddhist practices and introduced writing and laws forms a long tradition in Tibetan historical writing. The $d B a^{\prime} b z h e d$ is the earliest (known) text Tibetan law is firmly linked with religious morality. Examining sources on laws and legal practices in Tibet indicates that this account marks a shift in ideas, from the imperial-era concept of khrims as practical instruments used in judicial processes, to the idea that two types of law, royal and religious, were made by the emperors to guide the conduct of lay people and monastics. The concept of khrims, which is associated in Dunhuang texts with the practical business of property relations, commercial activity, theft, and personal injury, has come to refer to rules enshrining basic principles of Buddhist morality. The making of law is now presented as an act foundational to the establishment of the imperial order.

It was almost certainly not until the empire was collapsing that this narrative was worked out in these terms. This was over a century-quite possibly more-after Buddhism was first affirmed as the state religion in Tibet. Indian texts translated into Tibetan set out an ideal for a Buddhist king and his moral qualities and problematized the exercise of law through physical punishment. There are hints in some early Tibetan documents that writers were linking law with religious morality. However, it took several decades before ideas about moral (Buddhist) kingship found their way into Tibetans' own accounts of their imperial past.

We should not, of course, expect that the adoption of radically new religious ideas within an established polity should be either quick or straightforward. Anthropological literature from much later periods indicates the persistence of indigenous ritual practices among Tibetan populations, well after the basic acceptance of Buddhist ideas and sources of authority. ${ }^{67} \mathrm{It}$ is now generally

\footnotetext{
${ }^{66}$ Zimmerman, op. cit. 230-33.

${ }^{67}$ Charles Ramble, "How Buddhist are Buddhist communities? The construction of tradition in two lamaist villages", Journal of the Anthropological Society of Oxford 21 (1990), 185-97; Geoffrey Samuel, Civilized Shamans: Buddhism in Tibetan Societies' (Washington: Smithsonian Institution
} 
accepted that local ideas and practices developed in parallel with the established religion, rather than being relics of some pre-Buddhist cosmological and ritual world. We should probably regard the earlier period in the same way, expecting that parallel strands in thinking developed concurrently, in ways that were not always consistent. As is evident from the different ideas about law found in different parts of the $d B a^{\prime}$ bzhed, it was quite possible for writers to present inconsistent ideas within a single historical account.

The sources examined in this paper have indicated that although Buddhist ideas about government were circulating widely by the early ninth century, the attribution of the good order and excellence of the empire to the receipt of Buddhist texts did not emerge until some time later. Major changes in thinking about law and government, in fact, took place as the empire was collapsing. This was a period in which religious practices were diverging, legal processes must have become more localized, and the central authorities lost control over the application of the khrims. It was only at this point, it seems, that writers turned to ideas that had been current in Tibet for decades, notably the precepts of the ten virtues, and sought to create an account of law that had its roots in Buddhist principles. At the same time, they began to place the idea of law-making at the centre of their accounts of how civilization had been established by the early emperors.

These were idealistic accounts, and the ten virtues could not have provided a practical basis for administration and law. Nevertheless, at roughly the same time, we find a Tibetan ruler, Yeshe Öd, emphasizing the importance of khrims for the development of a moral polity, one in which the conduct of both monastics and the laity should be guided by ancient laws and Buddhist principles. The concept of moral law-even if not law based directly on the ten virtues-did resonate and so did the idea of a pairing between religious and royal laws, which we find in later histories. By the time the $d B a^{\prime}$ bzhed was written, the idea of Buddhist law was already taking hold. However difficult it was for the writers to give a satisfactory account of what this might look like in practice, the idea provided important ideological support for the practical projects of local rulers, while the concept of two laws came to underpin Tibetans' relations with their Mongol overlords. It is during this period of political turmoil that we find the origins of the claims, made frequently in later centuries, that Tibetan law was based on Buddhist principles.

Press, 1993); Fernanda Pirie, Peace and Conflict in Ladakh: The Construction of a Fragile Web of Order (Leiden: Brill, 2007), 105. 